\title{
APLIKASI PRINSIP BERKEKALAN WAKAF DI INSTITUSI PENGAJIAN TINGGI TERPILIH: PERSPEKTIF PERUNDANGAN
}

\section{Application of Perpetuity Principle of Waqf in Some Selected Higher Educational Institutions: A Legal Perspective}

\author{
Siti Umairah Ali Hamdan \\ Master Candidate, Department of Shariah and Law, \\ Academy of Islamic Studies, \\ University of Malaya, 50603 Kuala Lumpur. \\ umairah89@siswa.um.edu.my \\ Siti Mashitoh Mahamood \\ Associate Professor, Department of Shariah and Law, \\ Academy of Islamic Studies, \\ University of Malaya, 50603 Kuala Lumpur. \\ mas68@um.edu.my
}

\begin{abstract}
The study outlines the application of perpetuity principle of waqf in Higher Educational Institutions (HEI). This principle is an important element distinguishing between waqf and other philantrophic instrument such as zakāh, charity, gift and others. The article will discuss the concept and application of perpetuity principles of waqf by focusing on the potential of waqf management conducted in some selected Higher Educational Institutions (HEI). This case study method involved three (3) universities which have implemented waqf in their institutions, namely Universiti Islam Malaysia (UIM), University Putra Malaysia (UPM) and International Islamic University of Malaysia (IIUM). The data obtained through interviews and documentation methods will be analyzed by descriptively and comparatively. This study has found that there is no direct interpretation of perpetuality according to the existing waqf laws, therefore, section 47 of the Enactment of Wakaf Selangor 2015
\end{abstract}


regarding the application of Hukm Syarak if there is a lacuna in waqf law may be used. Therefore, the perpetual element of waqf in HEI can be seen through three aspects, namely the accumulation of waqf fund consisting of permanent and non-permanent assets, raising waqf funds involving investment, rental contract and several development projects conducted by the universities and the activities of distribution waqf funds to the beneficiary are expected to provide long-term returns to the institutions.

Keywords: waqf, perpetuity, endowment, law

\section{KONSEP WAKAF DALAM ISLAM}

Konsep wakaf adalah tertumpu kepada pembekuan atau pemegangan aset yang diwakafkan dan penyaluran manfaat harta berkenaan untuk digunakan bagi faedah benefisiari wakaf. Hal ini yang membezakan di antara wakaf dengan instrumen filantrofi yang lain seperti sedekah, zakat dan sebagainya. Wakaf pada dasarnya adalah merupakan amalan yang diinterpertasi melalui tindakan Rasulullah SAW yang telah mewakafkan Masjid Quba' pada tahun 622M. Hal ini juga dibuktikan sebagaimana hadis yang diriwayatkan oleh 'Umar bin Shaybah dari 'Amr bin Sa'ad bin Mu'adh yang bermaksud:
"Kami bertanya tentang wakaf yang terawal dalam Islam? Orang-orang Ansar mengatakan adalah wakaf Rasulullah SAW..." (al-Shawkāni, 1973: 129)

Amalan berwakaf ini juga diteruskan oleh para sahabat pada zaman Rasulullah SAW, di mana Saidina 'Umar RA telah mewakafkan tanah yang beliau perolehi di Khaybar untuk kebajikan umat Islam. Begitu juga dengan wakaf telaga al-Rumah oleh Saidina 'Uthmān RA yang telah memberikan manfaat yang besar kepada masyarakat. Amalan berwakaf ini semakin popular dan dikembangkan sehingga digunapakai oleh masyarakat barat melalui istilah endowmen (Monica M. Gaudiosi, 1988: 1244).

Dari sudut bahasa, wakaf berasal dari perkataan Arab iaitu waqf, waqf merupakan kata terbitan (mașdar) dari kata kerja waqafa. Ia mempunyai pelbagai makna mengikut tujuan dan penggunaan ayat itu sendiri. Dari segi bahasa, waqf memberi makna berhenti (السكن)), menegah (المنع) dan menahan (الحبس). Perkataan menahan (الحبس) lebih sinonim digunakan oleh kebanyakan ahli fiqh kerana ianya lebih hampir kepada pengertian syarak. Manakala, menurut istilah perundangan Islam, wakaf didefinisikan sebagai suatu bentuk dedikasi harta sama ada secara terang (sarīh) atau sindiran (kināyah) di mana harta (substance) berkenaan ditahan dan hanya manfaatnya sahaja 
yang diaplikasi kepada tujuan-tujuan kebajikan sama ada berbentuk umum mahupun khusus (Siti Mashitoh, 2007: 62).

Dalam mengesahkan sesebuah perwakafan terdapat empat elemen penting yang merangkumi Pewakaf (wāqif), benefisiari wakaf (mawqūf lahu), harta wakaf (mawqūf alayh) dan sighah wakaf ( $\bar{l} j \bar{a} b$ qabül). Dalam perihal pengurusan harta wakaf, para fuqaha' mazhab bersepakat menyatakan bahawa wakaf perlu diurus tadbir oleh mutawalli/nazir wakaf. Mutawalli atau nazir wakaf boleh terdiri daripada seseorang individu yang dilantik oleh pewakaf ataupun sebuah institusi (Mohd Zain, 1982).

Perbincangan berkaitan dengan prinsip utama perwakafan merupakan perkara penting dalam membezakan diantara konsep wakaf dan juga instrumeninstrumen kebajikan yang lain. Berdasarkan kepada hadis 'Umar, terdapat tiga bentuk syarat utama yang membentuk sesuatu wakaf. Di antara prinsipprinsip tersebut adalah (1) tidak boleh ditarik balik/dibatalkan (irrevocability), (2) tidak tertakluk kepada penjualan dan pemindahan (inalienability) dan (3) berkekalan (perpetuity).

\section{PRINSIP BERKEKALAN WAKAF MENURUT PERUNDANGAN ISLAM}

Para sarjana Islam mempunyai pelbagai pandangan dalam menjelaskan berkaitan elemen kekal sesuatu perwakafan.

Majoriti dalam kalangan fuqaha' termasuk juga mazhab Zahiri dan Syiah Imamiyyah bersetuju bahawa elemen kekal adalah merupakan syarat mutlak sesuatu perwakafan melainkan mazhab Maliki dan pandangan Abu Hanifah yang tidak mensyaratkan elemen kekal bahkan mengharuskan wakaf dibuat secara bertempoh (Abu Zahrah, 1959: 74).

Perbincangan fiqh berkaitan elemen kekal boleh dilihat dalam tiga keadaan iaitu merangkumi (1) berkekalan dari sudut tempoh masa perwakafan, (2) berkekalan dari sudut harta yang diwakafkan, dan (3) berkekalan dari sudut manfaat wakaf yang disalurkan kepada benefisiari yang tidak akan habis.

Yang dimaksudkan sebagai berkekalan dari sudut tempoh masa ialah apabila sesuatu harta telah diwakafkan, maka harta tersebut hendaklah menjadi harta wakaf selama-lamanya dan ianya tidak boleh dibatasi dengan masa (Abu Zahrah, 1959: 75). Oleh yang demikian, mazhab Shāfi'ī berpandangan elemen kekal adalah menjadi syarat mutlak kepada harta wakaf tanpa terikat dengan masa berdasarkan kepada niat/tujuan wakaf yang dibuat atas dasar qurbah.

Manakala as-Sharbin̄̄ pula berpandangan syarat kekal itu adalah mengikat tanpa melihat kepada tujuan wakaf sama ada melibatkan qurbah atau 
sebaliknya. Ianya juga turut dipersetujui oleh Ibn Hanbal dan Ibn Qudāmah. Di dalam al-Mugn̄̄, Ibn Qudāmah membuat penambahan dengan menjelaskan bahawa tidak sah sekiranya wakaf tersebut mengikat syarat seperti jual beli, dihibahkan dan dikembalikan semula kepada pewakaf kerana bertentangan dengan prinsip wakaf, makala mazhab Zahiriyyah pula menyatakan walaupun terdapat syarat jual beli semasa wakaf dilakukan, wakaf tersebut adalah sah dan syarat adalah terbatal sepertimana yang dinyatakan oleh Ibn Hazm di dalam kitab al-Muhalli.

Muhammad Ibn Hasan pula menegaskan bahawa elemen kekal adalah syarat utama dalam mewujudkan wakaf dan perlu disebutkan di dalam șighah wakaf sama ada secara lafaz ataupun tersirat. Abū Yūsuf juga mempunyai pandangan yang sama tetapi tidak perlu ditekankan di dalam șighah wakaf (Abū Zahrah, 1959:75). Hal ini berbeza dengan pandangan Abū Hanifah dan Mazhab Malikī yang tidak mensyaratkan elemen kekal dalam sesuatu perwakafan bahkan mereka berpandangan bahawa sah sesuatu perwakafan yang dibuat secara bertempoh.

Keadaan kedua elemen kekal adalah dilihat melalui perspektif harta yang diwakafkan. Dalam hal ini, terdapat beberapa percanggahan pandangan dalam kalangan fuqaha' terutama melibatkan harta wakaf (subject matter). Para fuqaha' mazhab bersepakat berkaitan kesahan harta tidak alih (immovable) seperti tanah, masjid dan rumah untuk dijadikan sebagai harta wakaf dengan mengambilkira sifat harta tersebut yang bersifat kekal dan tidak boleh dipindah. Ianya membolehkan manfaat daripada harta tersebut untuk dimanfaatkan secara berterusan. Walaupun begitu, para fuqaha' mempunyai pandangan yang berbeza dalam membincangkan berkaitan dengan wakaf harta alih (movable) (Siti Mashitoh, 2007: 65-66).

Menurut Abū Yūsuf, mewakafkan harta alih secara sendiri adalah tidak sah kecuali jika membabitkan kuda dan peralatan perang berdasarkan kepada dalil perwakafan Khalid Ibn al-Walid. Manakala, Muhammad Ibn Hassan mempunyai pandangan yang berbeza di mana beliau berpandangan bagi mengesahkan perwakafan sesuatu harta perlu juga melihat kepada 'urūf atau kebiasaan masyarakat setempat (Siti Mashitoh, 2007, 65). Oleh yang demikian, wakaf dalam harta-harta yang boleh dijadikan barang bermuamalah seperti kapak, penyodok termasuk dinar dan dirham, kain kapan dan periuk kawah adalah diharuskan. Justeru itu, fuqaha' dari kalangan mazhab shafi'i, mengharuskan perwakafan harta alih termasuklah harta yang boleh dijual beli selagi mana manfaat harta tersebut boleh dinikmati secara berterusan.

Selain daripada itu, elemen kekal juga boleh dirujuk melalui perspektif penerima manfaat wakaf. Muștafa al-Khin, Mușțafa al-Bugho dan A'li 
Sharbaji menyatakan pandangan tafsiran kekal kepada 'kekal dimanfaatkan' yang boleh direalisasikan menerusi tempoh kekal secara relatif dan tidak semestinya kekal selama-lamanya. Apa yang penting adalah harta wakaf itu boleh menghasilkan sesuatu atau hasilnya menyamai sesuatu upah (Muștafa al-Khin, Mușțafa al-Bugho dan A'li Sharbaji, 2004: 541). Dalam hal ini kekal di manfaatkan ini juga boleh dilihat dalam konteks penerima wakaf yang tidak akan terputus sebagai contoh fakir miskin. Mazhab Shāfi' $\overline{1}$ mengharuskan perwakafan kepada penerima wakaf yang tidak terputus dengan melihat melalui dua (2) keadaan iaitu keadaan pertama, mewakafkan harta kepada penerima yang tidak terputus seperti fakir miskin, para mujahidin, penuntut ilmu dan seumpamanya. Dan yang kedua mewakafkan harta kepada penerima yang terputus seperti seorang lelaki tertentu dan kemudiannya diwakafkan pula kepada benefisiari yang tidak terputus misalnya fakir miskin (Shirāzī, t.t.: 576). Manakala mazhab Hanbalī pula mengharuskan wakaf yang terputus benefisiarinya dimanfaatkan oleh orang yang dekat dengan pewakaf dengan bersandarkan kepada dalil:

"Sedekah kamu kepada orang miskin mendapat pahala sedekah sedangkan sedekah kamu kepada kaum kerabatmu mendapat pahala sedekah dan pahala menyambung silaturrahim." 1

Begitu juga dengan pandangan Monzer Kahf yang merupakan seorang sarjana kontemporari telah mendefinisikan semula maksud wakaf sebagai:

"As the perpetual dedication of benefits of a valuable, the value of which is amortized subsequently, and its proceeds or revenue are later spent on walfare of the named beneficiaries."

1 Diriwayatkan oleh Aḥmad bin Hanbal, Musnad al-Imām Ahmad bin Hanbal, Bāb al-Thānī fĩ al-Ruqba wa fỉhi Fashlan, vol. 4 (Mișr: Maktabah al-Maymuniyah), 17; Tirmidhī, Abī 'Isā Muḥammad bin 'Isā, al-Jāmi' al-Kabīr, Bāb Mā Jā'a fī al-Șadaqah 'ala zi al-Qurbah, vol. 2 (Beirūt: Dār al-Gharb al-Islāmī, 1996), no. hadith 658, 39; al-Qazwin̄̄, Abī 'Abd Allāh Muhammad bin Yazid, Sunan Ibn Majah, Kitāb al-Zakāh, Bab Fadhlu Șadaqah, vol. 1 (Dār al-Aḥyā' al-Kutub al'Arabī), no. hadith 1844; al-Bukharī, Abī 'Abd Allāh Muhammad bin Ismā'īl, Sahịh Bukharī, Kitāb al-Zakāh, Bāb al-Zakāh 'ala Zawjī wa al-Aytām fĩ al-Hijr (Beirūt: Dār Ibn Kathīr, 2002), no. hadith 1466, 357; Abī Husin Muslim bin Hajjāj al-Qushayrī al-Nisayburī, Șaḥịh Muslim, Kitab al-Zakāh (Riyāḍ: Dār alTaybah, 2006), no. hadith 1000, 446. Hadis yang diriwayatkan oleh Bukharī dan Muslim menggunakan matan yang berbeza dengan merujuk kepada hadith yang diriwayatkan oleh Zainab, isteri kepada 'Abd Allāh bin Mas'ud yang telah bertanyakan kepada Rasulullah SAW berkenaan sedekah kepada suaminya dan anak-anak yatim yang menjadi tanggungannya. Maka Rasulullah SAW menjawab: yang bermaksud: “mereka mendapat dua pahala iaitu pahala kerabat dan pahala sedekah.." 
Definisi ini membenarkan harta atau objek wakaf bersifat sementara (temporary) dan memberikan penegasan kepada sifat berkekalan ke atas nilai manfaat dari harta atau aset yang diwakafkan. Manfaat tersebut akan diagihkan kepada aktiviti kebajikan sepertimana yang dituntut oleh pewakaf. Contoh harta atau objek yang bersifat sementara adalah seperti wang tunai, saham dan sebagainya (Mohd Tahir \& Abd Hamid, 2006: 27-38).

Justeru itu, dapat diperhatikan bahawa para fuqaha' bersetuju bahawa elemen kekal perlu diwujudkan sebagai salah satu prinsip wakaf. Akan tetapi mereka mempunyai pandangan yang berbeza dalam menentukan sama ada elemen kekal boleh dianggap sebagai syarat sah wakaf ataupun bukan suatu syarat sah.

\section{IPT SEBAGAI MUTAWALLI WAKAF MENURUT UNDANG-UNDANG}

Berbincang berkaitan pengurusan wakaf. Istilah mutawalli, nāzir dan qayyim adalah sinonim dengan maksud pengurus wakaf. Ibn Manzuūr di dalam kitabnya Lisān al-'Arab menyatakan bahawa al-nāzir (الناظر) adalah (الحافظ) yang bermaksud seseorang yang menjaga, memelihara, mengelola dan mengawasi (Ibn Manzūr, 1990: 218). Manakala, dari sudut istilah, para fuqaha' menakrifkan nāzir adalah seseorang yang berkuasa terhadap seluruh hal ehwal wakaf, berperanan sebagai wakil pewakaf dan wasiatnya setelah dia meninggal dunia (Ibn 'Ābidīn, 1966: 458).

Perbincangan fuqaha' berkaitan perlantikan nāzir tidak hanya dispesifikkan pengurusannya kepada kerajaan sahaja, bahkan pewakafjuga mempunyai kuasa untuk melantik individu tertentu dalam menguruskan harta wakaf. Walaupun begitu, undang-undang wakaf di Malaysia telah memperuntukkan bahawa Majlis Agama Islam Negeri (MAIN) adalah merupakan pemegang amanah tunggal harta wakaf di setiap negeri. Hal ini boleh diperhatikan sebagaimana peruntukan Seksyen 89 Enakmen Pentadbiran Agama Islam Selangor 2003 yang menyatakan:

Seksyen 89. Majlis menjadi pemegang amanah tunggal wakaf, nazr dan amanah

"Walau apa pun apa-apa peruntukan yang berlawanan yang terkandung dalam mana-mana suratcara atau perisytiharan yang mewujudkan, mengawal, atau menyentuh perkara itu, Majlis hendaklah menjadi pemegang amanah yang tunggal-

Semua wakaf, sama ada wakaf am atau wakaf khas;

Semua nazar am dan 


\begin{abstract}
Segala jenis amanah yang mewujudkan apa-apa amanah khairar bagi menyokong dan memajukan agama Islam atau bagi faedah orang-orang Islam mengikut Hukum Syarak, bagi apa-apa harta yang tersentuh oleh wakaf nazr 'am atau amanah itu dan terletak di dalam Negeri Selangor." 2
\end{abstract}

Peranan dan tanggungjawab MAIN dalam hal perwakafan adalah termasuk perihal perletahakkan harta wakaf, ${ }^{3}$ pindahmilik harta wakaf, mendaftar dan merekod harta wakaf dalam sesebuah negeri, ${ }^{4}$ memelihara, membangunkan dan memastikan harta wakaf diproduktifkan selaras dengan hasrat pewakaf. ${ }^{5}$

Saban hari, penglibatan institusi selain daripada MAIN dalam pengurusan wakaf semakin mendapat perhatian kerana potensi wakaf pada hari ini yang melibatkan wakaf tunai mampu membantu mensejahterakan ekonomi khususnya umat Islam dan pembangunan wakaf secara lebih pesat. Hal ini juga termasuk pengaplikasian wakaf sebagai salah satu sumber pembiayaan universiti.

Di Malaysia, terdapat beberapa buah universiti yang telah mengaplikasi wakaf dengan menggunakan pelbagai terma termasuk wakaf, sedekah jariah, endowmen fund, perpetual endowmen dan sebagainya. Menurut penelitian yang dilakukan penulis, terdapat sebanyak enam (6) buah universiti awam yang terdiri daripada UKM, UPM, UIAM, UiTM, USIM dan UTM yang telah mengamalkan konsep wakaf dan endowmen sebagai salah satu sumber penjanaan dana universiti. Manakala sebanyak empat (4) buah universiti Swasta yang terdiri daripada UIM, KUIS, AiU dan MEDIU juga telah mengaplikasi wakaf dalam pengurusan universiti (Siti Mashitoh \& Asmak A.R, 2015: 432).

Oleh yang demikian, terdapat hanya beberapa negeri yang telah menggubal dan mempunyai peruntukkan yang memberikan kuasa kepada Majlis Agama

$2 \quad$ Seksyen 89 Enakmen Pentadbiran Agama Islam (Negeri Selangor) 2003; Seksyen 61 Akta Pentadbiran Agama Islam (Wilayah-wilayah Persekutuan) 1993; Seksyen 5, Enakmen Wakaf (Negeri Sembilan) 2005; Seksyen 89 dan 96, Enakmen Pentadbiran Agama Islam (Negeri Johor) 2003; Seksyen 32 Enakmen Wakaf (Negeri Melaka) 2005.

3 Seksyen 5 Enakmen Wakaf Selangor 2015.

4 Seksyen 15 Enakmen Wakaf Selangor 2015.

5 Rujukan kepada Enakmen Wakaf Selangor 2015: Seksyen 26 (1) berkaitan dengan pembangunan mawquf; Seksyen 29 pembahagian manfaat, kepentingan atau keuntungan; Seksyen 39 akaun dan laporan kumpulan wang wakaf, seksyen 36 mewujudkan kumpulan wang wakaf; seksyen 40 rujukan kepada jawatankuasa fatwa berkaitan dengan persoalan hukum syarak; dan seksyen 44 berkaitan dengan kawalan Majlis ke atas harta wakaf; 
Islam Negeri (MAIN) melantik mutawalli/nāzir khas wakaf di antaranya adalah di negeri Johor melalui kaedah-kaedah wakaf Johor 1983 berkaitan perlantikan nazir khas wakaf (Mohd Ali Don, 2011), seksyen 39 Enakmen Wakaf Negeri Sembilan 2005 berdasarkan peruntukan perlantikan ejen atau orang yang kompeten dan berkelayakan dalam mengurus wakaf dan yang terbaru adalah seksyen 4 Enakmen Wakaf Selangor 2015. Enakmen Wakaf Selangor 2015 telah memperuntukkan perlantikan nazir khas sebagaimana berikut:

Majlis sebagai pemegang amanah tuggal bagi semua wakaf

4(1) "Majlis hendaklah menjadi pemegang amanah tunggal bagi semua wakaf yang terletak di dalam Negeri Selangor dan hendaklah mempunyai kuasa untuk:

(a) mewujudkan perbadanan

(b) melantik atau memberi kebenaran bertulis kepada mana-mana orang untuk menjadi pentadbir atau pengurus dan memegang apa-apa mawquf bagi pihaknya; dan

(c) Mengiktiraf pelantikan mana-mana pentadbir atau pengurus dalam keadaan yang mana waqif telah pun melantik pentadbir atau pengurusnya sendiri tertakluk kepada terma dan syarat yang ditetapkan oleh Majlis.

(2) Mana-mana pengurus atau pentadbir yang dilantik di bawah perenggan (b) dan (c) hendaklah mempunyai kewajipan dan tanggungjawab sebagaimana yang ditetapkan oleh Majlis.

(3) Majlis boleh menarik balik pengiktirafan pelantikan pentadbir atau pengurus yang dilantik oleh waqif yang pada pendapat Majlis adalah wajar untuk berbuat sedemikian.

(4) Majlis hendaklah mempunyai kuasa untuk melakukan semua perkara yang suai manfaat atau semunasabahnya perlu bagi atau bersampingan dengan pelaksanaan kewajipan dan tanggungjawab di bawah Enakmen ini. " 6

Walaupun negeri-negeri lain tidak mempunyai peruntukan sedemikian, pendekatan kerjasama (joint venture) di antara MAIN dan mana-mana badan/institusi dalam memajukan ekonomi umat Islam juga boleh diaplikasi berdasarkan kepada peruntukan seksyen 7 Enakmen Pentadbiran Agama Islam

6 $\quad$ Seksyen 4 Enakmen Wakaf (Negeri Selangor) 2015. 
Negeri-negeri ${ }^{7}$ (Siti Mashitoh, 2007: 80). Walau bagaimanapun, pengurusan wakaf yang dilaksanakan di sesebuah negeri, Majlis Agama Islam Negeri (MAIN) adalah merupakan pemegang amanah tunggal harta wakaf yang berperanan sebagai penyelia pengurusan wakaf dan dalam masa yang sama berperanan sebagai principal regulator bekaitan wakaf untuk membuat peraturan dalam memberikan kebenaran kepada individu atau institusi tertentu dalam menguruskan wakaf, akan tetapi pengurusannya adalah perlu dikawal selia oleh Majlis agar harta wakaf dapat dipelihara dan direkod dengan baik. Penulisan artikel ini akan lebih menyentuh pemakaian peruntukan di dalam Enakmen Wakaf Selangor 2015 kerana ketiga-tiga IPT yang dikaji adalah IPT yang terletak di dalam negeri Selangor berdasarkan kepada perkara 2 senarai negeri Perlembagaan Persekutuan yang meletakkan bidangkuasa wakaf kepada Negeri.

\section{METODOLOGI KAJIAN}

Kajian ini adalah berbentuk kualitatif dengan menggunapakai kajian kes di tiga buah Intitusi Pengajian Tinggi yang bertaraf universiti di sekitar negeri Selangor. Pengumpulan data kajian ini menggunakan metod kajian kepustakaan melalui kitab-kitab fiqh, buku-buku berkaitan wakaf, artikel dan kertas kerja persidangan serta melibatkan proses temu bual pegawai wakaf di tiga buah universiti. Pemilihan universiti ini adalah berdasarkan beberapa kajian literatur yang pernah dilakukan di dalam kajian-kajian terdahulu merangkumi pengurusan organisasi, proses kutipan dan agihan dana wakaf di universiti berkenaan. Tiga buah universiti tersebut adalah:

a) Universiti Islam Malaysia (UIM) (Abd Manaf, 2012);

b) Universiti Islam Antarabangsa Malaysia melalui IIUM Endowment Fund, UIAM (Siti Mashitoh \& Asmak A.R, 2015: 441) dan

c) Universiti Putra Malaysia melalui Unit Dana Wakaf Ilmu UPM (Siti Zakiah \& Hairunnizam, 2014: 216-225).

Untuk mencapai kepada objektif kajian, data-data yang diperolehi, di analisis menggunakan metod deskriptif dan komparatif bagi ketiga-tiga buah universiti dengan menilai keselarasan pelaksanaannya sama ada mematuhi kehendak syariah dan undang-undang wakaf yang telah digubal.

7 Seksyen 7 Enakmen Pentadbiran Agama Islam Negeri Selangor; Seksyen 7 Akta Pentadbiran Agama Islam Wilayah Persekutuan 1993; Seksyen 7 Enakmen Pentadbiran Agama Islam Negeri Melaka 2002. 


\section{APLIKASI PRINSIP BERKEKALAN WAKAF DI IPT}

Sebagai sebuah badan korporat, sesebuah universiti mampu menjana instrumen wakaf dalam jangka masa yang panjang sebagai salah satu pelaburan berbentuk kebajikan yang mampu dimanfaatkan secara berterusan. Perbincangan elemen kekal sepertimana yang telah dibincangkan di atas adalah menjelaskan bahawa para fuqaha' bersepakat bahawa elemen kekal adalah syarat penting dalam mewujudkan sesuatu wakaf. Hal ini juga boleh dikaitkan dengan pandangan Imam al-Syarbini yang menyatakan elemen kekal sesuatu wakaf adalah bagi membezakan di antara wakaf dan sedekah biasa.

Menurut laporan KPT, di antara sumber pendapatan universiti adalah melalui yuran-yuran pelajar. Saban hari, dilihat bahawa yuran pengajian pelajar meningkat di sebabkan antara lain faktor peningkatan kos pengurusan dan kemudahan infarstruktur yang ditawarkan dalam sesebuah universiti. Hal ini menyebabkan terdapat dalam kalangan pelajar yang cemerlang tetapi tidak mempunyai wang yang mencukupi untuk membayar yuran pengajian. Justeru itu, wakaf di IPT menawarkan alternatif dalam menangani masalah ini.

Menurut hasil temu bual yang dijalankan, terdapat pelbagai aktiviti wakaf yang dilaksanakan di universiti berkenaan. Harta yang disalurkan kepada universiti adalah merangkumi harta alih dan tidak alih. Harta alih adalah dalam bentuk wakaf tanah manakala harta tidak alih kebiasaanya melibatkan wakaf tunai. Wakaf harta alih dan tidak alih yang diserahkan kepada Universiti berkenaan akan digunakan secara produktif melalui pelbagai aktiviti yang dirancang untuk tujuan pengumpulan dana dan penambahan nilai aset yang diwakafkan. Berdasarkan kepada data yang diperolehi, penulis telah mengenalpasti potensi wakaf yang dilaksanakan di universiti-universiti berkenaan melalui aktiviti-aktiviti pengumpulan dan agihan dana. Penulis mengklasifikasikan sifat berkekalan wakaf boleh dilihat melalui beberapa bahagian iaitu (1) berkekalan dari sudut strategi pengumpulan dana, (2) berkekalan dari sudut penjanaan dana dan (3) berkekalan dari sudut agihan manfaat wakaf.

Konsep berkekalan wakaf yang diamalkan di IPT berkenaan boleh dilihat sepertimana rajah berikut: 


\section{Rajah 1: Sifat berkekalan Wakaf di Institusi Pengajian Tinggi}

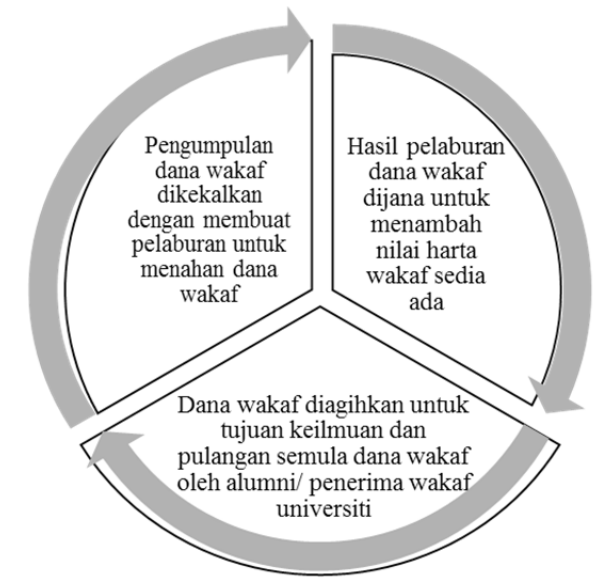

Sumber: Analisis Penyelidik

\section{Berkekalan dari Sudut Strategi Pengumpulan Dana}

Pengumpulan dana universiti biasanya melibatkan harta alih dan tidak alih. Wakaf harta tidak alih sepeti tanah tidak menimbulkan isu berkekalan kerana tanah adalah merupakan harta tidak alih dan sifatnya adalah tetap dan tidak boleh bergerak. Manakala, perwakafan secara wang tunai pula adalah menjadi salah satu produk popular yang diamalkan di ketiga-tiga universiti. Isu yang timbul adalah bagaimana untuk mengekalkan dana wakaf yang diperoleh dalam bentuk harta alih seperti wang tunai? Sepertimana yang disebutkan dalam perbincangan berkaitan konsep wakaf, sesuatu harta wakaf mestilah tidak susut nilai dan boleh mendatangkan manfaat, oleh yang demikian, menurut pandangan Anas Zarqa' sesuatu pelaburan harta wakaf hendaklah berasaskan prinsip meningkatkan keuntungan (Hari Candra, 2009: 111). Justeru itu, universiti sebagai nazir yang dilantik oleh pewakaf bertanggungjawab dalam merancang aktiviti dan projek-projek yang mampu meningkatkan manfaat harta wakaf.

Sebelum mengulas lebih lanjut berkaitan hal ini, penjelasan berkaitan aktiviti pengumpulan dana akan dibincangkan terlebih dahulu bagi melihat aktiviti pengumpulan dana di universiti-universiti yang terlibat. Dalam hal ini, terdapat universiti yang tidak mengehadkan pengumpulan dana kepada dana wakaf semata-mata tetapi juga melibatkan pengumpulan dana zakat dan sumbangan daripada pelbagai pihak. Hal ini sepertimana yang diamalkan di IEF dan UIM. Manakala Dana Wakaf Ilmu UPM lebih memfokuskan pengumpulan dana wakaf sahaja tanpa melibatkan instrumen lain. 
Pelbagai metod kutipan wakaf dikenalpasti di DWI UPM di antaranya adalah seperti pengumpulan dana melalui organisasi seperti syarikat-syarikat, hasil mudarabah, intensif penerbitan, jurnal dalaman, e-claims, cimb clicks, peti derma statik, skim potongan gaji dan kaunter. Jumlah kutipan dana wakaf UPM daripada tahun 2012 sehingga Disember 2014 adalah mencecah RM5,918,582.05. Statistik jumlah keseluruhan kutipan mengikut saluran boleh diperhatikan dalam jadual berikut:

Jadual 1: Kutipan Dana Wakaf Ilmu UPM dari tahun 2012 sehingga 2014.

\begin{tabular}{lrrr}
\hline \multicolumn{1}{c}{ Kaedah Kutipan } & \multicolumn{1}{c}{ Jan-Dis 2012 } & Jan-Dis 2013 & \multicolumn{1}{c}{ Jan-Dis 2014 } \\
\hline Kaunter & $301,178.18$ & $41,896.95$ & $185,515.41$ \\
Potongan Gaji & $96,412.00$ & $124,751.00$ & $139,237.00$ \\
Peti Besi & $87,993.02$ & $150,514.59$ & $185,515.41$ \\
Cimbclicks & $8,380.00$ & $13,512.47$ & $9,912.07$ \\
E-Claims & $3,131.39$ & $7,651.30$ & $10,435.67$ \\
Jurnal Dalaman & $27,180.00$ & $100,390.43$ & $57,253.94$ \\
Organisasi & $1,752,780.00$ & $1,116,748.00$ & $1,016,397.90$ \\
Insentif Penerbitan & $75,712.84$ & $51,435.66$ & - \\
Faedah Simpanan Tetap & $74,099.57$ & $95,524.74$ & $189,073.77$ \\
Agihan Manfaat & & & $(22,994.00)$ \\
\hline Jumlah Keseluruhan & $\mathbf{2 , 4 2 6 , 8 6 7 . 0 0}$ & $\mathbf{1 , 7 0 2 , 4 2 5 . 1 4}$ & $\mathbf{1 , 7 8 9 , 2 8 9 . 9 1}$ \\
\hline
\end{tabular}

Sumber: Laporan kutipan wakaf UPM 2014.

Berdasarkan jadual berikut, dapat diperhatikan bahawa daripada tahun 2012 sehingga 2013, kutipan dana wakaf adalah menurun sebanyak 71,441.86 dan kemudiannya meningkat semula pada tahun 2014 sebanyak 86, 864.77 yang menjadikan jumlah kutipan dana wakaf sebanyak 1,789,289.91. Menurut hasil temubual penulis bersama Pendaftar UPM, pengurangan kutipan dana di antara tahun 2012 dan 2013 adalah disebabkan faktor pengasingan unit wakaf daripada Pusat zakat dan Wakaf UPM di mana ketika awal penubuhan unit wakaf UPM adalah diletakkan sebagai satu unit kecil dibawah pentadbiran Pusat zakat dan Wakaf UPM, akan tetapi pada tahun 2013, unit wakaf dijadikan satu unit tersendiri yang diletakkan di bawah Pejabat Bendahari UPM.

Walaupun begitu, setelah dijadikan satu unit tunggal dalam pengumpulan dana wakaf, sepanjang 3 tahun tempoh unit ini ditubuhkan, jumlah dana DWI UPM semakin mendapat sambutan dalam kalangan warga UPM dan organisasi luar. Ini menunjukkan bahawa DWI UPM berpotensi untuk dimajukan pada masa akan datang. ${ }^{8}$

$8 \quad$ Nuruliman Ibrahim (Ketua Seksyen, Dana Wakaf Ilmu UPM) dalam temu bual bersama penulis, 25 Mac 2015. 
Selain daripada perancangan pengumpulan dana melalui aktiviti-aktiviti tersebut, DWI UPM juga ada membahagikan beberapa skim dalam penyaluran wakaf yang terdiri daripada skim umum, skim kitab, skim fasiliti dan skim kenderaan khas.

Hal ini berbeza pelaksanaannya sepertimana di UIM dan IIUM Endowment Fund, UIAM. UIM misalnya mempunyai harta wakaf sedia ada semenjak tahun 1955 lagi iaitu ketika UIM menggunakan nama Kolej Islam Malaya (KIM). Harta-harta wakafnya terdiri daripada harta alih dan tidak alih. Selain bergantung kepada harta wakaf sedia ada, UIM juga ada menerima sumbangan daripada individu perseorangan, Majlis Agama Islam Negeri dan syarikatsyarikat korporat. Bukan itu sahaja, UIM juga ada memperolehi harta wakaf dalam bentuk tunai dan buku-buku sama ada daripada individu dan syarikatsyarikat korporat. Walaupun masih baru ditubuhkan, aset-aset wakaf UIM kekal sehingga kini dan mempunyai nilai yang tinggi sehingga ke hari ini. ${ }^{9}$

Hal ini membuktikan bahawa aset wakaf khususnya dalam bentuk tanah adalah merupakan aset kekal dan mampu memberikan nilai yang tinggi dalam menjana pendapatan wakaf agar ianya mampu dimanfaatkan secara berterusan.

Manakala aktiviti pengumpulan dana oleh IIUM Endowment Fund (IEF) juga tidak hanya memfokuskan kepada pengumpulan dana wakaf sahaja tetapi juga melibatkan kutipan dalam bentuk sumbangan, zakat dan wakaf. Pelbagai produk yang dirancang oleh pengurusan wakaf IEF di antaranya adalah dalam bentuk sumbangan umum (general donation), Kempen RM1, Program Kafalah, Kerjasama zakat bersama dengan Lembaga Zakat Selangor, IIUM Perpetual Endowment Property Fund, IIUM Perpetual Endowment Cash Fund, IIUM Alumni Legacy Campaign dan sebagainya.

Menurut maklumat yang penulis perolehi, projek wakaf di IEF adalah dimulakan melalui sumbangan daripada individu dan syarikat korporat. Daripada sumbangan tersebut, IEF telah merangka startegi untuk menjadikan dana sumbangan tersebut kepada suatu bentuk pelaburan yang dikekalkan sama ada dalam bentuk bangunan ataupun pelaburan wang tunai. Hasil daripada sumbangan tersebut memberikan manfaat yang berkekalan kepada IEF mahupun kepada aktiviti keilmuan di UIAM. ${ }^{10}$

9 Zulfadlain Abdullah (Timbalan Pendaftar Bahagian Dana, Aset dan Wakaf, Universiti Islam Malaysia), dalam temu bual dengan penulis, 27 Mac 2015.

10 Mohamad Nasir Jaafar (Pengurus Bahagian Zakat IIUM Endowment Fund, Universiti Islam Antarabangsa Malaysia), dalam temu bual bersama penulis, 20 Mac 2015. 
Daripada perbincangan tersebut, dapat diperhatikan bahawa wakaf di universiti berkenaan melibatkan harta alih dan tidak alih. Dalam hal ini, tidak timbul isu berkaitan wakaf tidak alih misalnya wakaf tanah UIM, tetapi perbincangan aspek kekal adalah lebih menjurus kepada harta tidak alih sepertimana yang diperolehi DWI UPM dan IEF. Oleh yang demikian, sebagai memenuhi elemen kekal wakaf, terdapat dua (2) kaedah yang diaplikasi oleh universiti tersebut iaitu yang pertama (1) wakaf tunai tersebut akan ditukar kepada aset kekal misalnya dalam bentuk bangunan sepertimana yang dilakukan oleh IEF dan yang kedua (2) menyimpan wakaf tunai tersebut di perbankan patuh Syariah sepertimana yang di lakukan oleh DWI UPM dan IEF.

\section{Berkekalan dari Sudut Penjanaan Dana Wakaf}

Selain daripada mengekalkan nilai aset wakaf dalam bentuk bangunan dan pelaburan patuh Syariah, sesuatu aset wakaf juga boleh ditambah nilai dan digunakan secara produktif melalui kontrak sewaan dan pajakan bagi menambah pendapatan wakaf sebagaimana yang dilakukan oleh UIM, Dana Wakaf Ilmu UPM (DWIUPM) dan IEF.

Secara praktikalnya, tanah dan bangunan yang ditubuhkan menggunakan hasil wakaf bukan sahaja mampu dimanfaat oleh masyarakat bahkan juga mampu memberikan keuntungan kepada pengurus wakaf melalui perolehan hasil sewaan bangunan/tanah wakaf berkenaan. Sebagai contoh, penjanaan dana wakaf melalui penyewaan bangunan banyak diaplikasi pada masa kini khususnya di Institusi Pengajian Tinggi. Hal ini kerana selain daripada memberikan keuntungan melalui hasil sewaan ia juga membantu universiti menyediakan kemudahan infrastruktur kepada para pelajar di universiti seperti menyediakan premis photostat, kemudahan perbankan, premis perniagaan, kedai penjualan buku-buku dan sebagainya.

Pelaburan wakaf dalam bentuk bangunan ini telah diaplikasi di DWI UPM dan IEF. Dalam menjana pendapatan yang berterusan, DWI UPM telah merangka satu projek bangunan komersial di mana bangunan sedia ada di UPM misalnya Kompleks Muhammad Rashid dibaikpulih dan beberapa premis perniagaan diwujudkan untuk disewakan sebagai menjana pendapatan bulanan kepada Dana Wakaf Ilmu. ${ }^{11}$

11 Nuruliman Ibrahim (Ketua Seksyen, Dana Wakaf Ilmu UPM) dalam temu bual bersama penulis, 25 Mac 2015. 
Begitu juga dengan aplikasi wakaf di IEF, UIAM, di mana dana yang disumbangkan diproduktifkan dengan membina beberapa buah bangunan untuk manfaat warga UIAM. Pembinaan beberapa buah bangunan tersebut juga mampu menambah pendapatan UIAM melalui sewaan tapak-tapak perniagaan dan hasil sewaan tersebut digunakan sebagai pemberian biasiswa kepada para pelajar yang berkelayakan. Di antara wakaf bangunan tersebut adalah Kompleks Azman Hashim yang mempunyai pulangan sebanyak RM500,000 setahun, Asrama Sheikh Humaid, Putra Villa Condominium yang mempunyai 12 unit rumah untuk disewakan. ${ }^{12}$

Manakala, bagi Universiti Islam Malaysia (UIM) pula, tanah-tanah wakaf yang diperolehi semenjak tahun 1955 kekal sehingga ke hari ini. Dua (2) daripada tanah-tanah wakaf berkenaan telah disewa oleh Kementerian Pengajian Tinggi (KPM) dimana tanah wakaf UIM yang terletak di kelang Selangor disewakan kepada Sekolah Berasrama Penuh iaitu Kolej Islam Sultan Azlan Shah (KISAS) manakala tanah wakaf UIM di Petaling Jaya pula disewakan kepada Universiti Islam Antarabangsa Malaysia dengan menempatkan pelajar-pelajar dalam bidang asasi. ${ }^{13}$

\section{Berkekalan dari Sudut Agihan Dana Wakaf dalam Aktiviti Keilmuan}

Menurut perbincangan berkaitan agihan dana wakaf di universiti berkenaan adalah lebih melibatkan wakaf khas di mana manfaat wakaf digunakan untuk aktiviti keilmuan di universiti berkenaan. Di antaranya adalah melibatkan pemberian biasiswa dan bantuan kewangan kepada para pelajar. Selain itu, terdapat juga universiti yang menggunakan manfaat wakaf berkenaan untuk menerbitkan buku-buku ilmiah yang ditulis oleh ahli akademi di universiti berkenaan. Perbincangan berkaitan elemen kekal wakaf menurut perspektif benefisiari wakaf yang berterusan telah dibincangkan oleh Mazhab Shāfi‘ Dalam keadaan ini di antara benefisiari yang tidak akan terputus adalah penuntut ilmu.

Sebagai contoh, Dana Wakaf Ilmu UPM telah mengklasifikasikan agihan manfaat wakaf kepada skim wakaf pendidikan dan skim wakaf penerbitan. Skim wakaf pendidikan adalah merangkumi dermasiswa asasi yang diberikan

12 Mohamad Nasir Jaafar (Pengurus Bahagian Zakat IIUM Endowment Fund, Universiti Islam Antarabangsa Malaysia), dalam temu bual bersama penulis, 20 Mac 2015.

13 Zulfadlain Abdullah (Timbalan Pendaftar Bahagian Dana, Aset dan Wakaf, Universiti Islam Malaysia), dalam temu bual dengan penulis, 27 Mac 2015. 
sebagai bantuan kewangan kepada pelajar laluan pantas Pusat Asasi Sains Pertanian dan juga bantuan Dermasiswa Penyelidikan yang diberikan kepada pelajar tahun akhir bagi membantu mereka untuk menyelesaikan tugas projek tahun akhir bagi program ijazah sarjana muda. Agihan dana ini juga telah dijalankan pada tahun 2013 dan 2014 di mana melibatkan agihan kepada para pelajar UPM diberikan dalam bentuk bantuan pendidikan bagi pelajar asasi dan bantuan projek tahun akhir pelajar.

Selain daripada itu, agihan dana dalam bentuk penerbitan mushaf al-quran dan buku-buku oleh ahli akademik UPM juga telah dilaksanakan. Di antara projek agihan dana yang telah dijalankan adalah penerbitan mushaf al-Quran yang melibatkan agihan dana berjumlah RM30,000 iaitu pada tahun 2013 dan 2014 masing-masing sebanyak RM15,000. Buku memorial pada tahun 2013 berjumlah RM10,000, Mushaf Qiam iaitu agihan melibatkan penerbitan dari kalangan warga akademik UPM yang melibatkan agihan sebanyak RM10,000. Penerbitan al-Quran dan buku-buku ini sebahagiannya akan diwakafkan di surau-surau UPM dan sebahagiannya lagi akan dijual semula untuk tujuan wakaf dan pendapatan semuala wakaf UPM. ${ }^{14}$

Manakala di IEF pula menawarkan pelbagai bantuan biasiswa yang disediakan hasil daripada pelaburan wakaf yang dilaksanakan IEF. Di antaranya adalah Azman Hashim Ummatic Scholarship dan Sheikh Humaid Ummatic Scholarship. Berikut merupakan jadual berkaitan bilangan bantuan kewangan IEF yang telah diberikan kepada para pelajar daripada tahun 2006 sehingga tahun $2010:^{15}$

Jadual 2: Bilangan Pelajar yang Mendapat Bantuan Kewangan IEF

\begin{tabular}{ccccc}
\hline Year & $\begin{array}{c}\text { Under } \\
\text { Graduate }\end{array}$ & $\begin{array}{c}\text { Post } \\
\text { Graduate }\end{array}$ & Total & $\begin{array}{c}\text { Amount Spent } \\
(\text { RM })\end{array}$ \\
\hline 2006 & 802 & 152 & 954 & $1.76 \mathrm{~m}$ \\
2007 & 1033 & 138 & 1171 & $1.60 \mathrm{~m}$ \\
2008 & 1133 & 195 & 1328 & $2.35 \mathrm{~m}$ \\
2009 & 1329 & 335 & 1664 & $3.16 \mathrm{~m}$ \\
2010 & 1465 & 369 & 1834 & $3.79 \mathrm{~m}$ \\
Total & 5762 & 1189 & 6951 & $12.26 \mathrm{~m}$ \\
\hline
\end{tabular}

14 Nuruliman Ibrahim (Ketua Seksyen, Dana Wakaf Ilmu UPM) dalam temu bual bersama penulis, 25 Mac 2015.

15 Mohamad Nasir Jaafar (Pengurus Bahagian Zakat IIUM Endowment Fund, Universiti Islam Antarabangsa Malaysia), dalam temu bual bersama penulis, 20 Mac 2015. 
Sumber: Laporan IEF tahun 2010.

Jadual berkenaan menunjukkan bilangan pelajar yang mendapat bantuan kewangan daripada IEF hasil daripada pelbagai aktiviti pengumpulan dana iaitu bantuan zakat, biasiswa Ummatic Scholarship dan sebagainya. Daripada jadual berkenaan juga dapat diperhatikan bahawa jumlah bilangan pelajar yang menerima bantuan kewangan daripada IEF semakin meningkat daripada tahun ke tahun. Justeru itu, pelaksanaan Endowmen di IEF dilihat telah mencapai objektif penubuhannya iaitu membantu pelajar-pelajar yang cemerlang dengan memberi bantuan kewangan.

Manakala UIM belum lagi melaksanakan agihan dana wakaf, tetapi mereka mencadangkan untuk menyalurkan manfaat wakaf kepada aktiviti penyelidikan dan pembiayaan yuran pelajar. ${ }^{16}$ Agihan dana wakaf di IPT bukan sahaja mampu dimanfaatkan kepada para benefisiari iaitu pelajar dan universiti, bahkan juga mampu memberikan kesedaran kepada pelajar yang juga modal insan yang dilahirkan oleh universiti berkenaan untuk menyumbang semula kepada universiti setelah mereka tamat belajar. Hal ini juga dipraktikkan di negara Barat melalui istilah endowmen.

Menurut kajian yang dilakukan oleh Sutton Trust pada tahun 2014, terdapat 11\% pelajar yang telah menamatkan pelajaran di Universiti di Amerika telah memberikan sumbangan semula kepada universiti. Manakala, menurut Council of Aid Education, jumlah pendapatan daripada alumni pada tahun 2014 meningkat sebanyak $9.4 \%$ berbanding 2013 menjadikan jumlah endowmen yang diperolehi daripada alumni universiti sebanyak $\$ 9,850$ daripada $\$ 37,450$ dana endowmen terkumpul di pengajian tinggi di barat. Hal ini boleh dirujuk sepertimana rajah berikut:

16 Zulfadlain Abdullah (Timbalan Pendaftar Bahagian Dana, Aset dan Wakaf, Universiti Islam Malaysia), dalam temu bual dengan penulis, 27 Mac 2015. 
Rajah 2: Sumber Bantuan Sukarela bagi Pengajian Tinggi pada tahun 2014.

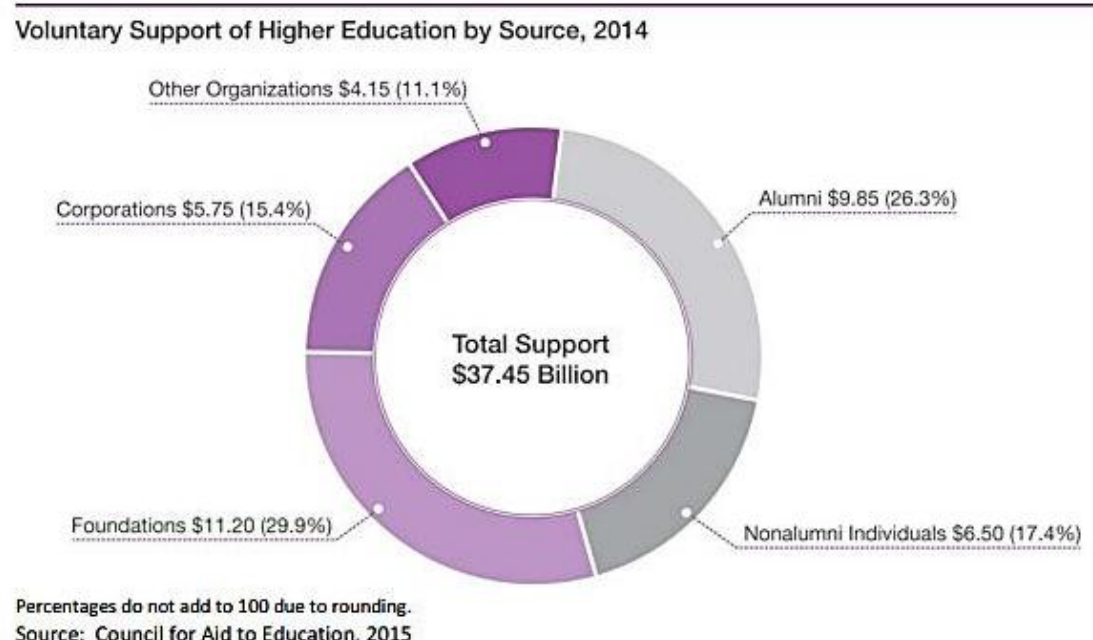

Sumber: Council for Aid to Education, 2015. ${ }^{17}$

\section{HASIL KAJIAN}

Berdasarkan perbincangan tersebut, tidak terdapat peruntukan khusus berkaitan tafsiran kekal wakaf menurut undang-undang. Oleh yang demikian, Seksyen 47 (2) Enakmen Wakaf Selangor 2015 adalah wajar untuk diperhatikan. Peruntukan tersebut adalah berkaitan dengan rujukan kepada hukum syarak sekiranya terdapat lakuna dalam perundangan wakaf yang telah digubal. Merujuk kepada hukum syarak, pelbagai tafsiran berkaitan dengan elemen kekal dibincangkan sama ada melibatkan elemen kekal terhadap harta wakaf itu sendiri, manfaat harta yang diwakafkan serta benefisiari wakaf yang tidak akan terputus.

Berdasarkan kepada aplikasi wakaf yang dijalankan diketiga-tiga IPT, perbincangan elemen kekal wakaf di ketiga-tiga IPT adalah selaras dengan kehendak undang-undang wakaf dan hukum syarak. Hal ini boleh diperhatikan dari sudut pengurusan di mana terdapat dua (2) buah IPT yang telah mendapat kebenaran untuk menguruskan wakaf melalui perlantikan sebagai wakil naziran daripada MAIS dan menggunakan pendekatan kerjasama (joint

17 Council for Aid to Education (2015), “Colleges and Universities Raise \$37.45 Billion in 2014 Harvard Raises \$1.16 Billion Gifts of Art Contribute to Strong Growth," http://cae.org/images/uploads/pdf/VSE-2014-Press-Release.pdf, dicapai pada 10 Februari 2016. 
venture) dengan Perbadanan Wakaf Selangor (PWS). Hal ini adalah selaras dengan peruntukkan seksyen 4 Enakmen Wakaf Selangor 2015. ${ }^{18}$ Walaupun begitu, hanya terdapat sebuah IPT sahaja yang tidak terlibat dengan Majlis kerana menggunakan istilah perpetual endowment. Menurut kajian, istilah endowmen juga adalah berasal daripada konsep wakaf dalam Islam kerana terdapat syarat harta endowmen yang perlu ditukarkan kepada aset kekal dan ini menyamai dengan konsep wakaf sepertimana yang telah dibincangkan.

Selain itu, dari sudut penjanaan dana wakaf yang berupa harta wakaf berbentuk harta tidak alih seperti tanah dan harta alih seperti wakaf tunai yang dilaburkan dalam bentuk pelaburan aset kekal seperti sewaan tanah dan bangunan serta simpanan di perbankan patuh Syariah juga membuktikan bahawa penjanaan dana yang dilakukan di IPT tersebut adalah mematuhi kepada kehendak Syariah dan undang-undang. Hal ini boleh diperhatikan sebagaimana peruntukan seksyen 19 (1) (c) Enakmen Wakaf Selangor 2015 berkaitan dengan syarat mawqūf iaitu selagimana harta wakaf tersebut mampu memberikan manfaat, kepentingan atau keuntungan kepada mawqüf 'alayh. ${ }^{19}$ Melalui proses penjanaan dana wakaf yang dilakukan di ketiga-tiga IPT membuktikan bahawa harta yang diwakafkan boleh dijana dan mampu memberi manfaat dalam jangka masa yang panjang kepada institusi pengurusan wakaf dan benefisiari yang ditentukan.

Berbincang berkaitan dengan agihan dana wakaf di IPT yang melibatkan bantuan pendidikan kepada para pelajar. Menurut mazhab Shāfi' $\overline{1}$, salah satu elemen kekal adalah dilihat dari sudut penerima manfaat yang tidak terputus. Penuntut ilmu adalah merupakan di antara benefisiari wakaf yang tidak akan terputus yang dapat menerima manfaat wakaf selain daripada fakir miskin. Berdasarkan kepada peruntukan seksyen 29 Enakmen Wakaf Selangor 2015, jika terdapat lebih daripada seorang mawqūf 'alayh dalam sesuatu wakaf khas dan wāqif tidak menentukan bahagian mereka masing-masing, maka ianya menjadi tanggungjawab perbadanan untuk membahagikan manfaat, kepentingan dan keuntungan di kalangan mereka. Perbadanan yang disebutkan di dalam peruntukan ini adalah merujuk kepada Perbadanan Wakaf Selangor (PWS) yang diberikan kuasa oleh Enakmen Wakaf Selangor 2015 mewakili Majlis dalam melaksanakan tugas pengurusan wakaf di dalam negeri Selangor. ${ }^{20}$

Hal ini juga boleh dirujuk dalam seksyen 2 berkaitan dengan tafsiran Perbadanan yang merujuk kepada Perbadanan Wakaf Selangor yang ditubuhkan melalui Perintah Penubuhan Perbadanan Wakaf Selangor 2011

18 Seksyen 4 Enakmen Wakaf Selangor 2015.

19 Seksyen 9 (1)(c) Enakmen Wakaf Selangor 2015.

20 Seksyen 8 Enakmen Wakaf Selangor 2015. 
[Sel. P.U. 8/2011]. Berdasarkan kepada aplikasi wakaf di ketiga-tiga IPT, hanya terdapat dua (2) buah universiti sahaja yang mempunyai jawatankuasa agihan manfaat tersendiri. Jawatankuasa ini akan menentukan pelajar yang berkelayakan dalam menerima agihan manfaat wakaf dalam bentuk biasiswa dan bantuan kewangan. Walaupun begitu, hanya Jawatankuasa Agihan Manfaat DWI UPM sahaja yang mempunyai wakil daripada MAIS untuk menentukan agihan wakaf, manakala jawatankuasa kewangan IEF hanya melibatkan pihak dalaman UIAM sahaja. Hal ini antara lain disebabkan ketidakterikatan IEF dengan Enakmen Wakaf Selangor 2015.

\section{KESIMPULAN}

Justeru itu, elemen berkekalan wakaf boleh dilihat daripada pelbagai aspek dan ianya tidak terhad kepada keperluan mewakafkan harta alih yang bersifat kekal sahaja, bahkan boleh melibatkan harta tidak alih yang juga boleh memberikan manfaat yang berterusan kepada aktiviti keilmuan. Agihan dana wakaf juga boleh diperhatikan secara tersirat melalui kelahiran pada cendekiawan Islam yang hebat hasil daripada perwakafan dalam bidang keilmuan ini. Wakaf ini juga dilihat dapat membantu dalam perkembangan ilmu pengetahuan yang mampu menyumbang kepada melahirkan manusia yang soleh. Sebagai contoh, penubuhan Madrasah Nizamiyyah oleh Sultan Nizam al-Mulk pada tahun 457H bukan sahaja dibiayai oleh institusi wakaf, malah wakaf yang disalurkan kepada institusi tersebut juga telah mewujudkan dana untuk membiayai para ulama', guru-guru dan pelajar sehingga nilainya mampu mencecah 600,000 dinar setahun.

Agihan dana wakaf di Institusi Pengajian Tinggi ini juga telah berjaya melahirkan tokoh dan ulama' terbilang seperti Imam al-Ghazali yang banyak menyumbangkan pengetahuan melalui penulisannya. Di antara buku-buku yang terkenal adalah kitab Ihya' 'Ulumuddin dan kitab ini juga dijadikan sebagai salah satu rujukan yang berautoriti dalam bidang fiqh. Selain itu, pembiayaan wakaf di Universiti al-Azhar juga telah melahirkan tokoh dan ulama' terbilang seperti Ibn Yunus yang merupakan pakar astronomi Islam, al-Musabbihi yang merupakan ahli sejarah Islam, al-Hufi ahli bahasa, Ibn Haitham dan sebagainya (Mohd Ridhwan, 2012: 228).

Justeru itu, boleh disimpulkan bahawa wakaf di IPT dilihat mempunyai potensi yang besar dalam membantu menjana pendapatan universiti. Konsep berkekalan yang diaplikasi di universiti melalui pelaksanaan wakaf secara korporat bukan sahaja membantu dalam penjanaan dana pendapatan universiti bahkan juga mampu menimbulkan kesan falsafah yang tersirat 
seperti sumbangan dalam ilmu pengetahuan dan amal bakti yang berterusan dikalangan benefisiari wakaf.

\section{RUJUKAN}

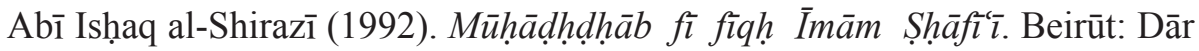
al-Shāmiyah.

Ahmad Abd. Manaf (2012). Mengapa Perlunya Universiti Islam Malaysia. Matang Cipta Sdn. Bhd.

Hari Candra (2009). 'Kajian Kaedah Harta Wakaf di Dompet Dhuafa' Republika, Indonesia.” Disertasi Sarjana, Jabatan Syariah dan Ekonomi, Akademi Pengajian Islam, Universiti Malaya, Kuala Lumpur.

Council for Aid to Education (2015). “Colleges And Universities Raise \$37.45 Billion in 2014 Harvard Raises \$1.16 Billion Gifts of Art Contribute to Strong Growth," http://cae.org/images/uploads/pdf/VSE-2014-PressRelease.pdf, dicapai pada 10 Februari 2016.

Mohamad Tahir Sabit Haji Mohammad \& Abdul Hamid Hj Mar Iman (2006). "Obstacles of the Current Concept of Waqf to the Development of Waqf Properties and the Recommended Alternative." Malaysian Journal of Real Estate, vol. 1, 27-38.

Mohd Afandi M.R, Muhammad Hamizan, Ahmad Zaki A.L \& Baharuddin S. (2014). "Wakaf Pengajian Tinggi: Konsep dan Kelestarian di Malaysia," dalam Pelestarian Institusi Wakaf Memperkasa Pendidikan Tinggi Negara, ed. Wan Kamal Mujani. Bangi: Fakulti Pengajian Islam, Universiti Kebangsaan Malaysia, 13-27.

Monica M Gaudiosi (1988). "The Influence of the Islamic Law of Waqf on the Development of the Trust in England: The Case of Merton College." University of Pennsylvania Law Review, vol. 136 (4), 1231-1261

Muhammad Abū Zahrah (1959). Muhadarāt fì al-Waqf, Ahmad 'Ali Mukhaymarah. Qāhirah: Jāmi'at al-Duwal al-'Arabiyah.

Muhammad b. 'Alī al-Syawkan̄̄ (t.t.). Nayl al-Awțār min Ahāāith Sayyid alAkhbār Syarh Muntaqa al-Akhbār Syarh Muntaqa al-Akhbār. Qāhirah: Muștafā al-Bab al-Halābī.

Muhammad Amin bin 'Umar bin 'Abd al-'Azīz Ibn 'Abidīn (1966). Rad al-Mukhtār 'ala al-Dur al-Mukhtār, vol. 4. Mesir: Mușțafā al-Bab alHalābī.

Muhạmmad Ibn Mukarram Ibn Manẓūr (1990). Lisān al- 'Arab, vol. 5. Beirūt: Dār Sadr. 
Muhammad Ridhwan Ab. Aziz (2012). Introduction to Islamic Instituitions in Economics and Finance. Nilai: USIM Publisher.

Mustafa Al-Khin, Mustafa al-Bugho \& Ali Asy-Syarbaji (2004). al-Figh alManhāji 'ala Mazhab al-Imam as-Shafi'i, terj. Kitab Fikah Mazhab Syafie, vol. 5. Kuala Lumpur: Pustaka Salam.

Siti Mashitoh Mahamood \& AsmakAb Rahman(2015). "Financing Universities through Waqf, Pious Endowment: Is It Possible?" Humanomics, vol. 29 (2), 80-87.

Siti Mashitoh Mahamood (2007). "Pembentukan Dana Wakaf Menurut Perspektif Syariah dan Undang-Undang Serta Aplikasinya di Malaysia." Jurnal Syariah, vol. 15 (2), 61-83.

Siti Zakiah Ali \& Hairunnizam Wahid (2014). "Peranan dan Kepentingan Dana Wakaf Institusi Pendidikan Tinggi di Malaysia," dalam Prosiding PERKEM Ke 9, vol. 9, 216-225.

Sutton Trust (2014). "Academic Assets: University Fundraising-An Update," http://www.suttontrust.com/wp-content/uploads/2014/08/academicassets-final.pdf., dicapai pada 10 Februari 2016.

\section{Statut}

Enakmen Wakaf Selangor 2015, Enakmen No. 15 Tahun 2015.

Enakmen Pentadbiran Agama Islam Negeri Selangor 2003, Enakmen No. 1 Tahun 2003.

\section{Temu bual}

Mohamad Nasir Jaafar (Pengurus Bahagian Zakat IIUM Endowment Fund, Universiti Islam Antarabangsa Malaysia), dalam temu bual bersama penulis, 20 Mac 2015.

Nuruliman Ibrahim (Ketua Seksyen, Dana Wakaf Ilmu UPM) dalam temu bual bersama penulis, 25 Mac 2015.

Zulfadlain Abdullah (Timbalan Pendaftar Bahagian Dana, Aset dan Wakaf, Universiti Islam Malaysia), dalam temu bual dengan penulis, $27 \mathrm{Mac}$ 2015. 